\title{
Otel Çalışanların İs Motivasyonu ve Çeşitli Demografik Değişkenlere Göre Farklılaşmast: Denizli Şehir Otellerinde Bir Araştırma
}

\author{
Work Motivation of Hotel Employees and Differentiation According to Various \\ Demographic Variables: A Research in Denizli City Hotels
}

\author{
Ahmet Çetin* \\ Mehmet BOYRAZ ${ }^{* *}$ \\ Songül ÖZER ${ }^{* * *}$
}

\section{$\ddot{O} Z$}

Bu çalışma turizm sektörü içerisinde önemli bir yere sahip otel işletmeleri çalışanlarının iş motivasyonlarının belirlenmesi ve otel departmanlarına göre çalışanların iş motivasyonlarındaki farklılıkların ortaya konması amacıyla gerçekleştirilmiştir. Çalışma Denizli ilindeki dört ve beş ylldızlı şehir otellerinde gerçekleştirilmiştir. Çalışmada otel işletmelerinin temel hizmet alanların oluşturan kat hizmetleri, servis, ön büro ve mutfak çalışanlarından yüz yüze anket yöntemiyle veri toplanmıştır. Araştırmadan elde edilen verilerin değerlendirilmesi sonucunda, çok boyutlu iş motivasyonu ölçeğinin alt boyutlarında kişisel düzenleme ve içsel motivasyon alt boyutlarında otel çalışanları arasında cinsiyete göre farklılık oluştuğu, diğer boyutlarda anlamlı bir fark olmadığ belirlenmiştir. Departmanlara göre ise, ön büro ile mutfak ve kat hizmetleri departmanları arasında motive olmama alt boyutunda ve servis ile mutfak arasında içe yansitılan düzenleme alt boyutunda farklılık olduğu belirlenmiştir.

\section{ANAHTAR KELIMELER}

Çok boyutlu İş Motivasyonu, Şehir Otelleri, Denizli

\begin{abstract}
This study was carried out in order to determine the motivation of the employees in the hotel enterprises which have an important place in the tourism sector and according to the departments of the hotel, to find out the differences in the work motivations of employees. The study was conducted in four and five-star city hotels in Denizli. In the study, data were gathered by face to face survey method, from the House Keeping, Service, Front Office and Kitchen which constitute the basic service areas of hotel enterprises. As a result of the data obtained from the study, it has been determined that there is a significant difference according to gender among employees in "identified regulation sub-dimension" of the scale and in the other subscales there is no significant differences. According to the departments, it is determined that there is a difference in the "amotivation sub-dimension" between the front office with the kitchen and housekeeping, and determined that there is a difference in "introjected regulation sub-dimension" between service and kitchen
\end{abstract}

KEYWORDS

Multi-Dimensional Work Motivation, City Hotels, Denizli

\begin{tabular}{|c|c|c|}
\hline \multicolumn{2}{|r|}{$\begin{array}{c}\text { Makale Geliş Tarihi / Submission Date } \\
\text { 10.07.2019 }\end{array}$} & $\begin{array}{c}\text { Makale Kabul Tarihi / Date of Acceptance } \\
\text { 29.09.2019 }\end{array}$ \\
\hline Attf & $\begin{array}{l}\text { Çetin, A., Boyraz, M. ve Özer, S. (2019 } \\
\text { Farklılaşmas1: Denizli Şehir Otellerin } \\
\text { Dergisi, } 22 \text { (2), 601-614. }\end{array}$ & $\begin{array}{l}\text { Motivasyonu ve Çeşitli Demografik Değişkenlere Göre } \\
\text { suk Üniversitesi Sosyal Bilimler Meslek Yüksekokulu }\end{array}$ \\
\hline
\end{tabular}

\footnotetext{
* Öğr. Gör. Pamukkale Üniversitesi Denizli Sosyal Bilimler MYO, Seyahat Turizm ve Eğlence Hizmetleri, cetina@ pau.edu.tr, ORCID: 0000-0002-0753-8175

${ }^{* *}$ Arş. Gör. Afyon Kocatepe Üniversitesi Turizm Fakültesi, Turizm İşletmeciliği, mboyraz@aku.edu.tr, ORCID: 0000-0001-6755-1999

${ }^{* * *}$ Dr. Öğr. Üyesi Van Yüzüncü Yıl Üniversitesi, Turizm ve Otel İşletmeciliği Yüksek Okulu, Rekreasyon ve Animasyon Bölümü songulduz@yyu.du.tr, ORCID: 0000-0002-5495-4729
} 


\section{GíRIŞ}

Emek faktörünün üretimin temelini oluşturduğu turizm işletmelerinde işgörenlerin performansının işletmenin verimliliği açısından önemli bir yer tuttuğu söylenebilir. Turizm işletmelerinin müşterilerine iyi hizmet sunabilmeleri, çalışan performansı ile yakından ilgilidir (Akova vd, 2015: 88). Sanayi devriminden sonra pek çok sektörde gerçekleşen makineleşme ve otomasyon (Eren, 2010: 497), turizm işletmelerinde belirli düzeyde etkili olmuş ancak emek faktörünün önemini ve işletme verimliliğine etkisini azaltmamıştır. İnsan kaynağı turizm işletmeleri için daima en önemli unsur olmaya devam etmiştir. Eğitilmesi ve temini uzun zaman alan nitelikli insan gücünün turizm işletmelerinde tutulması ve verimini artırıcı uygulamaların gerçekleştirilmesi turizm işletmeleri açısından her zaman önemli olmuştur (Kaya, 2007: 369). Turizm işletmeleri içinde önemli bir yer tutan otel işletmelerinde kaliteli hizmet sağlanması için insan kaynaklarından daha etkin faydalanmaları gerekmektedir (Tütüncü ve Demir, 2002: 11). İşletme içerisinde çalışanların verimini ve işletmeye bağlılıklarını artırmak için ele alınan konuların başında iş motivasyonu gelmektedir. İnsan kaynağından etkili yararlanmak için çalışanların morallerinin ve motivasyonlarının yüksek olması müşteriyle iyi ve olumlu ilişkilerin oluşturulmasını ve müşterinin kalite algısının yükselmesini sağlayacaktır (Akova, Kuşluvan ve Çifçi, 2015: 226).

Motivasyon, çalışanları harekete geçiren, onların davranışlarına yön veren bir güç, ihtiyaç ve çekincelerdir. Otel işletmeleri farklı birimlerde birçok insanın bir arada çalıştığı ve farklı departmanların eşgüdüm içerisinde işleri yerine getirdikleri işletmeler olarak, çalışanların çabalarını bir yönde ve belirli bir amaç çerçevesinde toplamak zorundadırlar (Güler, Demiralay ve Selvi, 2017: 31). Bu nedenle otel işletmelerinde her bir çalışanın müşteri memnuniyetine ve işletme performansına doğrudan ya da dolaylı etkisi olduğu söylenebilir. Dolayısıyla otel yöneticilerinin kendi sorumluluk alanlarındaki çalışanlardan en üst düzeyde fayda sağlamaları için onları en iyi şekilde motive etmeleri gerekir (Garih, 2005, 105). Otel işletmelerinde çalş̧an bireylerin farklı demografik yapıları ve çalıştıkları departmanın özelliklerine göre motivasyon durumları ve kaynakları farklı olabilmektedir. Yöneticilerin işletme amaçlarına ulaşabilmek için üretim ve hizmetin kalitesi ve miktarında doğrudan etkisi bulunan çalışanların verimlilik ve üretkenliğini artırmak için çalışanların motivasyon düzeylerini ve kaynaklarını bilmeleri önem arz etmektedir (Çivilidağ ve Şekercioğlu, 2017: 144).

$\mathrm{Bu}$ çerçevede araştırmanın amacını otel işletmelerinde çalışanların çok boyutu iş motivasyonu ölçeğine göre iş motivasyonlarının belirlenmesi ve çeşitli demografik değişkenlere göre farklılık gösterip göstermediğinin ortaya konması oluşturmaktadır. İşletmelerin çalışanların motivasyon kaynakları ve düzeylerini belirleyerek ve bu şekilde çalışanların motivasyonlarını artırmaya yönelik faaliyetlerle işletme verimliliğini artırmalarının mümkün olabileceği (Çetin, 2013), düşünüldüğünde bu çalışmanın ilgili taraflara fayda sağlaması umulmaktadır. Ayrıca çalışma, ölçeğin Türk kültürüne uyarlanması çalışmasının dışında, ölçeği turizm çalışanlarına uygulayan öncü çalışmalardan biridir.

\section{MOTIVASYON}

\subsection{Motivasyon Kavramı}

Motivasyon bireyleri harekete geçiren içsel bir süreci ifade etmek için kullanılan kavramdır. Robbins (1996: 212) motivasyonu, çalışanın bireysel bir ihtiyacının karşılanmasıyla ilgili olarak, örgütsel amaçlara ulaşmak için çaba harcamaya istekli olması olarak tanımlamaktadır. İş ve örgütsel psikolojideki motivasyon, bireyin varlığının ve ilerleyiş̧inin, yoğunluğunu ve eylem süresini etkileyen ancak bireyin ötesinde ortaya çıkan yoğun güç ile ilgilidir (Pinder, 1998: 11). Koçel (2005: 633) ise motivasyonu, kişilerin belirli bir amacı gerçekleştirmek üzere kendi arzu ve istekleri ile davranmaları ve çaba göstermeleri olarak açıklamaktadır. Genel olarak modern bakış açısı motivasyonu, bireylerin hedefleri etrafında bir araya getirilmiş zamana bağlı, çift taraflı ve tekrar eden duygusal, davranışsal ve bilişsel süreçler ve eylemler olarak tanımlamaktadır (Kanfer ve Chen, 2016: 7).

Motivasyon, fizyolojik ya da psikolojik bir eksikliği gidermek için gerçekleştirilen ya da bir amaca yönelik davranışı ya da dürtüyü harekete geçiren ihtiyaç ile başlayan bir süreçtir. Dolayısıyla, motivasyon sürecini anlamanın anahtarı, ihtiyaçlar, dürtüler ve güdüler ile teşvikler arasındaki anlam ve ilişkilerde yatmaktadır. İhtiyaçlar, dürtüler/güdüler ve teşvikler özetle şu şekilde tanımlanabilir (Luthans, 2010: 157):

İhtiyaçlar; fizyolojik veya psikolojik bir dengesizlik durumunda ortaya çıkan durumdur. Örneğin vücudun sıvı eksikliğinde vücuttaki hücrelerin suya ihtiyaç duyması fizyolojik, arkadaşsız kalındığında arkadaşa ihtiyaç duyulması ise psikolojik ihtiyaçtır. Her ne kadar psikolojik ihtiyaçlar bir eksikliğe bağlı olsa da, bazen farklılık gösterebilir. Çok başarılı bir geçmişe sahip olan bir kimsenin daha çok başarıyı istemesi bir eksiklikten ziyade fazlasını arzulaması ile ilgilidir. 
Dürtüler ve güdüler; ihtiyaçları tatmin etme zorunluluğu sonucu harekete geçmeyi sağlayan unsurlardır. Doğuştan insanlarda var olabilen güdüler olduğu gibi sonradan kazanılan güdülerde vardır. Ayrıca insanlarda içten gelebilen ve dışarıdan etkilerle gelişebilen güdüler olabilir. Fizyolojik ve psikolojik dürtüler eyleme yöneliktir ve bir teşvike ulaşmaya yönelik enerji verici bir itici güç sağlar. Motivasyon sürecinin tam kalbinde yer alırlar.

Teşvikler; motivasyon döngüsünün sonunda, bir ihtiyacı hafifletecek ve bir dürtüyü azaltacak unsur olarak tanımlanan teşvik yer almaktadır. Bir teşvike sahip olmak, fizyolojik ve psikolojik dengeyi sağlama ve bunlarla ilgili dürtüleri azaltma eğiliminde olacaktır.

\section{2.İş Motivasyonu}

Motivasyonun kaynağı olan güdüler literatürde birincil güdüler ile ikincil güdüler, içsel güdüler ile dişsal güdüler ve farkında olunan ile olunmayan güdüler olarak ele alınmaktadır (Seker, 2015: 22-23). Birincil güdüler doğuştan gelen fiziksel, biyolojik doğal güdülerdir. Bir güdünün birincil olabilmesi için iki temel şart gereklidir. Bunlardan birisi fizyolojik temelli olması ve öğrenilmemiş olmasıdır. Birincil güdüler yaşam için gerekli güdüler olarak adlandırılabilir. İkincil güdüler ise, her ne kadar hayati olmasa da günümüz dünyasında en az birincil güdüler kadar önemlidir. Çünkü insanlık sosyal ve ekonomik olarak gelişmiş ve çok daha kompleks bir hal almıştır (Luthans, 2010: 158). İş yaşamı içinde yer alan bireyin ihtiyaçları çok çeşitli olmakla birlikte söz konusu ihtiyaçların ortaya çıkardığı güdüler de kendine özgü olabilmektedir. İçsel ve dışsal olarak güdüler ise insanın iç dünyasından ya da çevresinden kaynaklı olmasına göre ayrılmaktadır. Herzberg'in ortaya attı̆g çift faktör teorisi, içsel ve dışsal güdüleme araçlarını birlikte ele almaktadır. Buna göre içsel güdüleme araçları işin içeriğine ilişkin unsurları içermekte ve çalışanı motive etmektedir. Dışsal araçlar ise iş tatminsizliğini gidermekle alakalıdır (Dündar vd, 2007: 109). Dışsal güdüler somut ve başkaları tarafindan görülebilir unsurlardan oluşur. Bir işyerindeki ücretler, promosyonlar veya ödül beklentisi ile oluşan güdüler ya da herhangi bir ceza korkusu ile oluşan güdüler, dışsal güdülerdir (Seker, 2015). İçsel motivasyon kaynakları ise kişinin herhangi bir dış etkiden bağımsız olarak sahip olduğu güdülerdir. Ödül ya da başka bir dışsal motivasyon kaynağının etkisi olmadan yapmaktan zevk aldığı, merak ettiği konulardan oluştuğu ve kişinin kendi yeteneklerini ortaya koyduğu durum olarak ifade edilmektedir (Brief ve Aldag, 1976: 497).

Genel olarak güdüler, iş motivasyonu teorileri için bir temel ve arka plan görevi görmektedir. İş motivasyonuna ilişkin teoriler; gereksinim kuramları ve süreç kuramları olmak üzere iki şekilde ele alınmaktadır. Gereksinim kuramları kişilerin ihtiyaçları olan yani içten gelen faktörlere ağırlık veren kuramlardır (Özer ve Topaloğlu, 2008). Çalışanları belirli bir yönde çalışmaya yönelten sebeplerin anlaşılması ile bu faktörlere hitap edilerek kurum amaçları doğrultusunda daha iyi yönlendirilebileceği varsayımına dayanır (Koçel, 1989: 304). Bu teorilerin asıl amacı kişilerin içinde bulunan ve onların davranışına yön veren güdülerle ilgili faktörleri belirlemektir ve esas olarak bireysel ihtiyaçlar üzerinde durur (Steers vd., 2004: 381). Literatürde gereksinim teorilerinin en önemlileri, Maslow'a ait olan ihtiyaçlar hiyerarşisi, Mc Gregor'un X ve Y kuramı ve Herzberg'in çift faktör kuramı olarak yer almaktadır. Bu kuramlar diğer kuramlara temel oluşturmuştur ve daha sonra çıan kuramlar bu kuramların eksikliklerinin giderilmesine yönelik geliştirilmiştir (Robins, 1998: 169).

\subsection{Motivasyon Teorileri}

Maslow ihtiyaçlar hiyerarşisi: Dünyada en çok bilinen motivasyon teorilerinin başında gelmektedir. Maslow, insanların temel ihtiyaçlarını tatmin etmek için ihtiyaç duydukları beş farklı ihtiyaç seviyesinin olduğunu öne sürmektedir (Mullins, 2010: 261). Bunlar, yiyecek, su, barınak gibi fiziksel ihtiyaçlar, insanların kendileri ve aileleri için güvenlik ihtiyaçları, sevmek ve sevilmek, arkadaşlık oluşturmak ve bir yere/gruba ait hissetme ihtiyaçlarını ifade eden sevgi ve ait olma ihtiyacı, kendine karşı saygı duyma ve başkalarının kendisine karşı saygı duyulması beklentisini ifade eden saygınlık ihtiyacı ve diğer ihtiyaçlar karşılandığında en üst düzeyde ortay çıktığı varsayılan kişinin yaratıcı potansiyelini ortaya çıkarttığı işler yaptığı kendini gerçekleştirme ihtiyacı seviyeleridir. Bu teorinin temelini alttaki ihtiyaçlar karşılandıkça üstteki ihtiyaçlar daha güçlü hissedilir hipotezi oluşturmaktadır (Latham, 2007: 31).

Douglas McGregor'un X ve Y kuramı: Çalışanların X ve Y olarak iki grupta değerlendirildiği ve her bir grup için oluşturulan varsayımların birbirine karşıt oluşturulduğu kuramdır. Teori X'in altında yatan varsayım, yönetim tarafından aktif müdahale olmadan, çalışanların örgütsel ihtiyaçlara karşı duyarsız olduğu, pasif kaldığı ve hatta direnç gösterdikleridir. Teori Y'nin varsayımı ise bunun tersi bir şekilde sorumluluk alabilme kapasitesine sahip olma ve örgütsel amaçlar doğrultusunda davranışları yönlendirmeye hazır olma durumunun insanlarda mevcut olduğunu, insanların bu özelliklerini kendi başlarına tanımasını ve geliştirmesini mümkün kılmanın yönetimin sorumluluğu olduğunu belirtmektedir (McGregor, 1957). McGregor'a göre Yönetimin en 
önemli görevi, örgütsel koşulları ve çalışma yöntemlerini insanların kendi hedefleriyle organizasyonel hedefleri birleştirebilecekleri ve kendi hedeflerine en iyi şekilde ulaşabilecekleri şekilde düzenlemektir (McGregor, 1960: 178).

Herzberg çift faktör kuramı: Herzberg'in çalışmalarının temeli Maslow'un ihtiyaç hiyerarşisinde iş tatminine neden olan şeylerin tersi olan şeyler iş tatminsizliğine neden olur mu? sorusu ile başlamıştır (Özkalp ve Kırel, 2016: 285). Herzberg'in çalışması çalışanların doyumsuzluğuna neden olan bazı koşulların eksikliğinin ya da yokluğunun giderilmesine rağmen çalışanları motive etmeye yeterli olmadığını göstermiştir. İşletme içerisinde hijyen faktörler olarak adlandırılan faktörler motive edici değildir ancak bu faktörlerin yokluğu iş doyumunu engellemektedir. Motive edici faktörler ise, motivasyona direkt olarak pozitif katk1 sağlayan etmenlerdir (Herzberg, 1974; Mullins, 2010).

Söz konusu kuramlardan yola çıkılarak ortaya atılmış diğer kuramlardan biri Alderfer'in ERG (VİG) kuramıdır. Bu kuram; Alderfer'in Maslov'un ihtiyaçlar hiyerarşisini temel alınarak özellikle örgütsel ortamdaki insan ihtiyaçlarına yönelik oluşturduğu kuramdır. Maslow’un kuramındaki basamakları var olma, ilişki ve gelişme olarak üç basamağa indirmiştir. Bu kurama göre, tatmin edilmemiş ihtiyaçlar güdüleyicidir (Yüksel, 2000: 140-141; Efil, 2006: 158-159). Bir diğer kuram ise, Murray, (1955) tarafindan ortaya konan ve McClelland, (1961) tarafından geliştirilen başarı ihtiyacı ya da öğrenilmiş ihtiyaçlar teorisidir. Murray'ın ihtiyaç baskı modeliyle açıkladığı kuramına göre bireylerin ihtiyaçları ile çevrenin özellikleri arasındaki uyum önemlidir ve bu uyumun seviyesi bir yerlerde ihtiyaçlara ilişkin doyum ya da ihtiyaçlara ilişkin yoksunluğa neden olur (Burger, 2006) geliştirilen teoriye göre, bireyler içinde yaşadıkları çevreden tecrübe edinerek çeşitli ihtiyaçlar öğrenirler. Öğrenilen bu ihtiyaçlar, bireylerin durumları algılama biçimlerini değiştirir ve o ihtiyacı edinmeyen kişiye göre farklı hareket etmelerine sebebiyet verir. McClelland bu ihtiyaçları; başarı ihtiyacı, güç ihtiyacı ve ilişki kurma ihtiyacı olmak üzere üç temel grupta toplamıştır (Cherrington, 1994).

Süreç teorileri ise, motivasyon ile ilgili ihtiyaç, değer, beklenti ve alg1 gibi değişken türlerini ve motivasyonun ortaya çıkması için bir araya geliş şekillerini açıklamaya çalışır (Metle, 2001:314). Diğer bir ifade ile süreç teorileri, motivasyonun bilişsel yönü ve güdüleyiciler arasındaki ilişkileri ele almaktadır. Bu teoriler, genel anlamda herhangi bir davranışın nasıl başladığı, nasıl yönlendirildiği ve nasıl sürdürüldügünü açıklamaktadır. Süreç teorilerinin en çok bilinenleri: Beklenti Teorisi, Şartlandırma ve Pekiştirme Teorisi, Eşitlik Teorisidir (Porte vd. 2003; Önen ve Kanayran, 2015: 52). Bu kuramları kısaca aşağıdaki gibi açıklamak mümkündür:

Beklenti Teorisi: Vroom, bir kişinin beklentilerine, değerlerine, tercihlerine ve araçlarına dayanan bilişsel bir teori geliştirmiştir (Latham, 2007: 45). Bu teorinin valens, araçsallık ve beklenti olmak üzere üç temel kavramı vardır. Valence belirli bir çıktıyı isteme derecesidir. Vroom valensi değerlerden ayırmaktadır. Bir kişi bir şeyi arzulayabilir ancak elde ettiğinde az bir tatmin yaşayabilir ya da bir kişi bazı şeylerden kaçındığı halde bu durum gerçekleştiğinde bundan memnuniyet duyabilir. Valence bir sonuçtan tatmin beklentisinin olmas1 durumudur. Bu haliyle, sonuçtan sağlanan gerçek tatmin olan değerden, farklı bir anlam kazanmaktadır. (Mullins, 2010: 270). Araçsallık, ikinci düzeyde bir sonuca ulaşmak için birinci düzey çıktının kullanımıdır. Örneğin maaş artışı, bir statü göstergesi olması ve kişinin ailesini daha iyi geçindirebilmesini sağlamak açısından araçtan ibaret olabilir (Şimşek, 1995: 206-207). Beklenti, bireyin belli bir davranışının onu belli bir sonuca ulaştıracağı yolundaki inancının şiddetidir. Araçsallık birinci ve ikinci düzey sonuçlarla ilişkili olmasına rağmen beklenti yalnızca birinci düzey sonuçlarla ilgilidir (Luthans, 2010).

Örgütlerde motivasyonla ile ilgili araştırmaların hedefinde performans ile iş tatmini arasındaki ilişkinin durumu yer alır. Lawler/Porter başarı/tatmin beklentisi kuramı, Vroom'un kuramının bu yönde geliştirilmiş şeklidir. Vroom'un kuramındaki üç temel unsur bu kuram içinde de yer almakla beraber bireyin yeterli "bilgi ve yetenek" sahibi olması gerekliliği vurgulanmaktadır. Motivasyonun ne kadar güçlü olsa da yetenek ve bilgi olmadan başarılı olunması mümkün değildir (Yüksel, 2000: 143). Bu kuramda ki bir başka kavramda algılanan rol kavramıdır. Örgütün her üyesi başarılı olabilmek için örgütün kendisine yüklediği role dair doğru bir anlayışa sahip olmalıdır. Aksi takdirde örgüt içi çatışmalar ortaya çıkabilir.

Şartlandırma ve Pekiştirme Teorisi: Klasik pekiştirme ve işlevsel pekiştirme olarak ele alınmaktadır. Klasik pekiştirme herkesin bildiği Pavlov'un köpekler üzerinde yaptığı deneylerle ortaya koyduğu koşullu refleks davranışlarıyla ilgilidir. İşlevsel pekiştirme ise insan davranışlarının içgüdüsel refleksler ile değil çevre tarafından ödüllendiricilerin, güçlendiricilerin ve cezalandırıcıların etkisiyle motivasyonların oluştuğunu ifade eder. Davranışlar, karşılığında ortaya çıkan tepki ve sonuçların şartlanmayı sağladığı varsayımına dayanmaktadır. Bireyler gerçekleştirdikleri bir davranış karşısında ödüllendirildiğini ya da davranışın olumlandığını görüyorsa davranışı yineleyerek pekiştirme yoluna gidecek aksi durumda ise davranışı yinelemeyecektir. (Stroh vd. 2008). Bu teoride olumlu pekiştirme, olumsuz pekiştirme, ortadan kaldırma ve 
cezalandırma şeklinde dört ana yöntem ile bireyden sergilenmesi beklenen davranış pekiştirilmeye ve alışkanlık haline getirilmeye çalışılır (Yüksel, 2000: 147).

Eşitlik (Ödül Adaleti) Teorisi: Ücret ve iş koşullarının neden motivasyonu tek başlarına belirlemediğini açıklamaya yardımcı olur. Herzberg'in çift faktör teorisi ve Maslow'un ihtiyaçlar teorisinden yola çıarak J. Stacey Adams'ın 1965'te ortaya koyduğu eşitlik teorisinde; çalışanlar, iş arkadaşlarıyla kendi çabalarını ve çabaları için aldıkları ödülleri sürekli olarak değerlendirir (Smit vd. 2011). Eğer algıladıkları kendi emek düzeyleri ile iş arkadaşlarınınki arasında önemli bir fark olduğunu görürlerse her iki taraf içinde eşitliği sağlamaya çalışacaklardır. Bunu yapmak için kendi performanslarını artıracak ya da düşürecek veya iş arkadaşlarının seviyesini ayarlamak için önlemler alacaklardır (Eren, 2010: 542).

Bugüne kadar motivasyona ilişkin çok sayıda kuram geliştirilmiş olmasına rağmen, bu kuramlardan herhangi birinin bireylerin güdülenmesine ilişkin unsurları tek başına açıklamaya ya da insanları motive etmeye yeterli olduğu söylenemez. İşletmeler için çalışanların işletme içindeki motivasyon düzeyleri önemli bir sorundur çükü işletmeler hedefledikleri verimlilik düzeyine ulaşmalarında doğrudan etkisi olan çalışanların verimli üretken olmalarını istemektedirler (Çivilidağ ve Şekercioğlu, 2017: 144). Bu yüzden örgütsel davranış ile ilgili çalışmaların teorik düzeyden uygulama alanına uyarlanması örgütler için oldukça önemlidir (Gagne vd. 2014). İşletmelerin çalışanlarının motivasyonlarını etkileyen unsurları bilerek, onların bireysel hedefleriyle işletme hedeflerini uyumlu hale getirmeleri ya da onların iş motivasyonlarını artırıcı unsurları işletme içi uygulamalarda kullanarak işletme verimini artırmaları mümkün olacaktır. Bu amaçla iş motivasyonunu belirlemek amacıyla çeşitli ölçekler geliştirilmiş ve kullanılmıştır. Bunlardan biri de "çok boyutlu iş̧ motivasyonu ölçeğidir.

\section{4.Çok Boyutlu İş Motivasyonu}

İş motivasyonu birçok alt boyuta sahip bir kavramdır. Çalışanların iş motivasyonlarını belirlemek için yapılan çalışmalarda iş motivasyonuyla ilgili objektif ve standart bir ölçme aracı geliştirmek amacıyla motivasyonun tüm boyutlarını kapsayacak bir ölçek geliştirebilmek için Gagne, Forest, Gilbert, Aube, Morin ve Malorni (2010), yaptıkları çalışmada iş motivasyonuna ilişkin bazı alt boyutlar ortaya koymuşlardır. Bunlar;

Motive Olmama (amotivation): Bir aktiviteye yönelik motivasyon eksikliği anlamına gelmektedir.

Dışsal Düzenleme (Maddesel - Sosyal) (extrinsic regulation social, extrinsic regulation material): Kişinin ödüllendirilme ve onay alma, cezalardan veya eleştiriden kaçınma, kişinin benlik saygısını artırma veya kişisel olarak değerli bir hedefe ulaşma gibi araçsal nedenlerle faaliyete girmesini ifade eder. Maddesel olanları daha çok kişinin maddi kazanç sağlaması ya da kayba uğramaması ile ilgiliyken Sosyal olanlar ise çevresinden kazanacağı beğeni, övgü, vb. manevi kazançları ya da eleştirilme, gözden düşme gibi kayıplardan çekinme ile ortaya çıkan davranışları ifade eder.

Içe Yansitılan Düzenleme (introjected regulation): Kişiye içsel olarak baskı yapan güçlerin dişavurumuyla işin yapılması sırasında ortaya çıkan davranışların düzenlenmesini ifade eder, yani utanç ve suçluluk gibi duyguların davranışları düzenlenmesi anlamına gelir.

Kişisel Düzenle me (identified regulation): Kişinin işe atfettiği değer ya da işe yüklediği anlamla ilgilidir. Yapılan işe atfedilen bu değer kişinin işin yapılmasına ilişkin davranışlarını belirler.

İçsel Motivasyon (intrinsic motivation): Çalışanın kendi uğruna bir aktivite yapmak olarak tanımlanır, yani, çalışanın işi ilginç, eğlenceli ya da heyecan verici bulduğu için yapması anlamına gelir.

Küresel dünyada örgütsel davranış teorilerinin kültürel, ekonomik ve çalışma koşullarında uygulanabilir olması gerekliliğinden hareketle geliştirdikleri "The Multidimensional Work Motivation Scale" ile dokuz farklı ülkede yedi dilde ölçeği uygulayarak daha önce iki dilde gerçekleştirdikleri çalışmayı geliştirmişlerdir. $\mathrm{Bu}$ çalışmanın Türk kültüründe geçerliliğini ölçmek için Çivilidağ ve Şekercioğlu 2017 bu ölçeği Türk kültürüne uyarladıkları çalışmalarını Antalya'da 6 farklı iş kolunda çalışan 506 kişiye uygulamışlardır. Bu uygulamadan elde ettikleri verilerin analizi sonucunda 19. maddenin orijinal çalışmadan farklı bir boyut altında çıkması nedeniyle, faktör deseni açısından sorun olmaması ve faktör isimlendirmede sorun yaratmaması için analiz dışı bırakmışlardır. Yapılan analizler sonunda orijinal kültürde belli faktörler altına toplanan ifadelerin hedef kültürde de aynı biçimde toplandığı belirlenmiş ve ölçeğin örgüt çalışanlarının iş motivasyonlarının ölçülmesi amacıyla kullanılabileceğini belirtmişlerdir.

Türk kültürüne uyarlarken ölçeğin uygulandığı gruplardan biri de turizm çalışanlarıdır. Ancak incelenen yazında bu ölçeğin başlı başına turizm çalışanlarının iş motivasyonlarını belirlemede kullanılmadığı görülmüştür. Bu çalışmanın bu anlamda da alana katkı sağlaması beklenmektedir. 


\section{YÖNTEM}

\subsection{Araştırma Modeli}

$\mathrm{Bu}$ araştırmada, otel çalışanlarının çok boyutlu iş motivasyonu ölçeğine göre iş motivasyonlarının belirlenmesi amacıyla niceliksel araştırma yöntemlerinden betimsel araştırma modeli kullanılmıştır. Betimsel araştırmalar bir konudaki mevcut durumu ortaya koymayı sağlayan araştırmalardır. Durumu değiştirmeye ve etkilemeye çalışmaz (Karasar, 2005: 77). Aynı zamanda araştırma otel çalışanlarının çeşitli demografik değişkenlere göre motivasyon düzeylerinin farklılaşıp farklılaşmadığını incelemek amacıyla yapıldığı için nedensel karşılaştırma modelini içermektedir.

\subsection{Evren ve Örneklem}

Çalışma Denizli' de yer alan şehir otellerinde gerçekleştirilmiştir ve Denizli İl Kültür ve Turizm Müdürlüğü verilerine göre Denizli'de turizm işletme belgeli 19 şehir oteli bulunmaktadır. Bu işletmelerden bir tanesi 5 yıldızlı, iki tanesi 4 yıldızlı, on bir tanesi 3 yıldızlı ve beş tanesi 2 yıldızlı olarak belirtilmektedir. Araştırma evreni olarak 5 yıldızlı ve 4 yıldızlı oteller ile çeşitli otel arama motorlarında 4 yıldız hizmet standardına sahip olduğu ifade edilen iki otel belirlenmiştir. Dört ve beş yıldızlı otellerin diğerlerine göre kurumsallaşma seviyelerinin daha yüksek olduğu ve departman seviyesinde yönetim uygulamalarının daha fazla olduğu düşünüldüğü için tercih edilmiştir. Bu otellerin kat hizmetleri, mutfak, servis ve ön büro departmanları seçilmiştir. Çalışmada bu departmanların seçilmesinin sebebi ise bu departmanların faaliyet bölümleri olması ve müşteri memnuniyet ya da memnuniyetsizliğinde yüksek etkiye sahip oldukları düşünüldüğü içindir. İşletmelerin çalışan sayıları ile ilgili bilgi vermekten kaçınmaları nedeniyle örneklem belirlenirken kolayda örnekleme yöntemi kullanılmıştır. Bu yöntemde amaç, belirlenen evrende isteyen her bireyin örnekleme dahil edilmesidir (Ural ve Kılıç, 2006:42). Katılımcıların demografik bulgularına ilişkin veriler Tablo 1'de yer almaktadır.

\section{Tablo 1: Katılımcıların Demografik Özelliklerine Göre Dağılımları}

\begin{tabular}{llll}
\hline & & \multicolumn{1}{c}{$\mathbf{N}$} & \% \\
\hline \multirow{2}{*}{ Cinsiyet } & Erkek & 74 & 59,2 \\
& Kadın & 51 & 40,8 \\
\hline \multirow{4}{*}{ Yaş } & $18-27$ & 54 & 43,2 \\
& $28-37$ & 45 & 36,0 \\
& $38-47$ & 22 & 17,6 \\
& $48-57$ & 4 & 3,2 \\
& 58 ve üstü & 0 & 0 \\
\hline \multirow{4}{*}{ Eğitim } & İlkokul & 13 & 10,4 \\
& Ortaokul & 18 & 14,4 \\
& Lise & 38 & 30,4 \\
& Önlisans & 33 & 26,4 \\
Medeni & Lisans & 23 & 18,4 \\
Durum & Lisansüstü & 0 & 0 \\
& Bekar & 57 & 45,6 \\
& Evli Çocuklu & 42 & 33,6 \\
Çalıştı̆̆ı & Evli Çocuksuz & 13 & 10,4 \\
Departman & Boşanmış & 13 & 10,4 \\
& Kat Hizmetleri & 28 & 22,4 \\
& Servis & 32 & 25,6 \\
& Mutfak & 30 & 24,0 \\
& Önbüro & 35 & 28,0 \\
\hline
\end{tabular}

$\mathrm{Bu}$ kapsamda işletmelerden her departmandan çalışmaya katılmayı kabul eden çalışanlara anket uygulanmıştır. Uygulanan 140 anketin değerlendirilmesi sonucunda analize uygun olmayan 15 adet anket çıkartılmış ve 125 anket analiz edilmiştir. Çalışmaya katılan otel çalışanlarının demografik değişkenlere göre dağılımı Tablo 1'de verilmiştir. Katılımcıların \%59,2 si erkek, \%40,8'i kadınlardan oluşmaktadır. Yaş gruplarına göre dağılımlarda $18-27$ yaş aralığ $1 \% 43,2$ ile en yoğun grubu oluşturmaktadır. Sonrasında sırasıyla 28-37 yaş grubu \%36, 38-47 yaş grubu \%17,6, 48-57 yaş grubu \%3,2 olarak dağılmaktadır. Katılımcıların eğitim değişkenine göre dağılımlarına bakıldığında \%30,4 ile lise mezunları en büyük grubu oluşturmaktadır. $\% 26,4$ ile ön lisans mezunları ikinci sırada, \%18,4 ile lisans mezunları üçüncü sırada, \%14,4 ile ortaokul mezunları dördüncü sırada ve \% 10,4 ile ilkokul mezunları beşinci sırada yer almaktadır. Katılımcıların büyük çoğunluğunu bekar çalışanlar \% 45,6 oluştururken, evli çalışanlar \%44 ile ikinci sırada ve boşanmış çalışanlar $\% 10,4$ ile son sırayı oluşturmaktadır. Çalıştıkları departmanlara göre dağ 1 lım oranları ön büro \%28, servis $\% 25,6$, mutfak $\% 24$ ve kat hizmetleri \%22,4 olarak gerçekleşmiştir. 
Demografik verilere bakıldığında Denizli'deki şehir otellerinde çalışanların büyük kısmının genç çalışanlardan oluştuğu, ağırlıklı olarak lise ve önlisans derecesinde eğitime sahip oldukları görülmektedir. Bekar bireylerin ve erkeklerin otellerde çalışmayı daha çok tercih ettikleri görülmektedir.

\subsection{Veri toplama aracı}

Araştırmanın verilerini toplamak amacıyla Gagne vd. (2010) tarafından geliştirilen ve Çivilidağ ve Şekercioğlu (2017) Türk kültürüne uyarlaması yapılan 19 maddeden oluşan beșli Likert türünde "The Multidimensional Work Motivation Scale" Çok Boyutlu İş Motivasyonu Ölçeği kullanılmıştır. Ölçek motive olamama, dışsal düzenleme maddi, dışsal düzenleme sosyal, içe yansitılan düzenleme, kişisel düzenleme ve içsel motivasyon olmak üzere 6 boyuttan oluşmaktadır. Çivilidağ ve Şekercioğlu (2017) ölçeğin Türk kültürüne uyarlaması çalışmasında önce dilsel eşdeğerliliği belirleme çalışmalarını gerçekleştirmiş̧ler, ikinci aşamada pilot uygulamayı altı farklı meslekten 166 işgörene uygulamışlardır. Ölç eğin uygulama aşamasında 647 kişiye uygulanan ölçekten geçerli 506 veri setine faktör analizi uygulanmış KMO değeri= .83 bulmuşlardır. Yapı geçerliliğine ilişkin yapılan Doğrulayıcı Faktör Analizi sonucunda Modele ilişkin uyum indekslerinin $\chi 2(119)=330.07, \mathrm{p}=.000, \chi 2 / \mathrm{sd}=2.77, \mathrm{RMSEA}=.059, \mathrm{GFI}=.93, \mathrm{AGFI}=.90, \mathrm{SRMR}=.59$ ve $\mathrm{CFI}=.96$ olduğunu tespit etmişlerdir. Alt ölçek puanları açısından iç tutarlılık bağlamında güvenilirliği belirlemek amacıyla Cronbach alfa hesaplamaları ise; motive olmama alt ölçeği için .72, içsel motivasyon alt ölçeği için .73, dışsal düzenleme-sosyal alt ölçeği için .78, kişisel düzenleme alt ölçeği için .76, dışsal düzenleme-maddesel alt ölçeği için .80 ve içe yansitılan düzenleme alt ölçeği için .73 olduğunu belirlemişler ve bu sonuçlar çerçevesinde kabul edilebilir düzeyde yapı geçerliliği kanıtı elde edildiğini ifade etmişlerdir (Çivilidağ ve Şekercioğlu, 2017).

İş motivasyon ifadelerinin alt boyutlarının orijinal ölçekle ne derece uygun dağılım gösterdiğini belirlemek için bu çalışmada da faktör analizi yapılmış ve verilerin bu analize uygun olduğu, Kaiser-Meyer Olkin (KMO) değeri $(0,766)$ ve Cronbach's Alpha değeri $(\alpha=0,855)$ ve $(p=0,000)$ ile tespit edilmiştir. Bu sonuçlarla ölçeğin yapısal geçerliliğe sahip olduğu ve faktör analizi için uygun olduğu ortaya çıkmıştır. Yapılan analizde Çivilidağ ve Şekercioğlu'nun Türk kültürüne uyarladıkları ölçekte olduğu gibi 19. madde alınmamıştır. Tablo 2'de faktör analizi sonuçları verilmiştir.

Çok boyutlu iş motivasyonu ifadelerine ilişkin faktör analizi sonuçları tablosunda, dönüştürülmüş̧ bileşenler matrisi ve faktör analizi sonuçları verilmiştir. Tabloda orijinal değişkenler ve faktörler arasındaki korelasyonlar görülmektedir. Bir değişken hangi faktörün altında mutlak değer olarak daha büyük ağırlığa sahipse o değişken altında yer aldığı faktörle ilişki içerisindedir. Faktörler ve değişkenler arasında daha yoğun ilişkiyi göstermek amacıyla Büyüköztürk (2016), önerdiği üzere 0,45 ve altında yükleme oranına sahip değişkenler dikkate alınmayacak şekilde analiz gerçekleştirilmiş, ifadelerin hepsinin faktör yükleri 0,45 üzerinde gerçekleşmiş ve faktör yükleri 0,637 ile 0,952 arasında olan değişkenler Tablo 2'de gösterilmiştir. Öz değerleri birden fazla olanlar dönüştürülmüş bileşenler matrisi olarak verilmiştir. Faktörlerin dağ 11 lımı; 1 . Faktör: Kişisel Düzenleme, 2. Faktör: Motive Olamama, 3. Faktör: Dışsal Düzenleme Maddi, 4. Faktör: İçsel Motivasyon, 5. Faktör: İçe Yansitılan Düzenleme ve 6. Faktör: Dışsal Düzenleme Sosyal şeklinde gerçekleşmiştir. 
Tablo 2: İş Motivasyonu Boyutlarına İlişkin Faktör Analizi

\begin{tabular}{|c|c|c|c|c|c|c|c|c|c|}
\hline \multirow{2}{*}{$\mathbf{F}$} & \multirow{2}{*}{$\begin{array}{r}\text { İş } \\
\text { Motivasyon }\end{array}$} & \multirow{2}{*}{ Ort. } & \multirow{2}{*}{ SS } & \multicolumn{6}{|c|}{ Faktör Yükleri } \\
\hline & & & & 1 & 2 & 3 & 4 & 5 & 6 \\
\hline \multirow{3}{*}{ 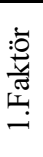 } & İfade 2 & 3,89 & 1,216 & ,952 & & & & & \\
\hline & İfade 1 & 4,12 & 1,168 & ,903 & & & & & \\
\hline & İfade 3 & 4,04 & 1,124 &, 862 & & & & & \\
\hline \multirow{3}{*}{ 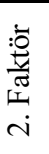 } & İfade 11 & 2,61 & 1,366 & & ,938 & & & & \\
\hline & İfade 12 & 2,76 & 1,448 & & ,915 & & & & \\
\hline & İfade 10 & 2,75 & 1,299 & & ,758 & & & & \\
\hline \multirow{3}{*}{ 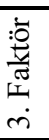 } & İfade 5 & 3,80 & 1,052 & & & ,909 & & & \\
\hline & İfade 6 & 3,78 & 1,096 & & & ,825 & & & \\
\hline & İfade 4 & 3,58 & 1,290 & & & ,671 & & & \\
\hline \multirow{3}{*}{ 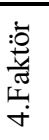 } & İfade 17 & 3,41 & 1,192 & & & & 874 & & \\
\hline & İfade 18 & 3,84 & 1,233 & & & & 827 & & \\
\hline & İfade 16 & 3,53 & 1,174 & & & & 786 & & \\
\hline \multirow{3}{*}{ 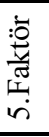 } & İfade 13 & 3,72 & 1,207 & & & & & ,956 & \\
\hline & İfade 14 & 3,72 & 1,227 & & & & & ,917 & \\
\hline & İfade 15 & 3,78 & 1,298 & & & & &, 637 & \\
\hline \multirow{5}{*}{ 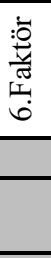 } & İfade 8 & 3,67 & 1,183 & & & & & & ,846 \\
\hline & İfade 7 & 3,88 & 1,179 & & & & & &, 807 \\
\hline & İfade 9 & 3,42 & 1,186 & & & & & &, 710 \\
\hline & & \multicolumn{2}{|c|}{ Öz Değerler } & 5,65 & 2,62 & 2,18 & 1,62 & 1,28 & 1,07 \\
\hline & \multicolumn{3}{|c|}{$\begin{array}{r}\text { Faktörlerin Tanımlama Fark } \\
\text { Yüzdesi }\end{array}$} & 31,44 & 14,55 & 12,13 & 9,02 & 7,16 & 5,99 \\
\hline & \multicolumn{3}{|c|}{ Ölçek Cronbach's Alpha } & \multicolumn{6}{|c|}{0,855} \\
\hline \multicolumn{4}{|c|}{ Toplam Farkın Açıklanma Oranı } & \multicolumn{6}{|c|}{80,317} \\
\hline
\end{tabular}

Anketlerden elde edilen verilerin faktör analizi sonucunda iş motivasyonu alt boyutlarının uyarlanan ölçekteki ile aynı şekilde dağıldı̆̆ı, ifadelerin motive olmama (amotivation), dışsal düzenleme - sosyal (extrinsic regulation social), dişsal düzenleme - maddesel (extrinsic regulation material), içe yansitılan düzenleme (introjected regulation), kişisel düzenleme (identified regulation) ve içsel motivasyon (intrinsic motivation) olmak üzere altı boyutta toplandığı görülmüştür.

\section{ARAŞTIRMA BULGULARI}

$\mathrm{Bu}$ bölümde otel çalışanlarının "çok boyutlu iş motivasyonu ölçeğine" göre iş motivasyonlarının belirlenmesi ve demografik değişkenlere göre farklılaşması ile ilgili bulgular ve yorumlar yer almaktadır.

Çalışmadan elde edilen verilerin değerlendirilerek otel çalışanlarının iş motivasyonlarının belirlenmesi ve gruplar arasındaki farklılıkların tespiti için t-testi ve Anova analizleri yapılmış ve elde edilen bulgular aşağıda verilmiştir. Cinsiyetler arasındaki farklılıklara ilişkin Tablo 3'de yer alan sonuçlara bakıldığında, erkek ve kadın katılımcılar arasında kişisel düzenleme ve içsel motivasyon alt boyutlarında anlamlı bir farklılık olduğu görülmektedir.

Tablo 3: Cinsiyete İlişkin T-Testi Sonuçları

\begin{tabular}{|c|c|c|c|c|c|c|}
\hline Boyutlar & Cinsiye & & Ort. & Std. S. & $t$ & Sig (p) \\
\hline \multirow{2}{*}{ Motive Olamama } & Erkek & 74 & 2,684 & 1,2286 & \multirow{2}{*}{, 302} & \multirow[b]{2}{*}{,763 } \\
\hline & Kadın & 51 & 2,751 & 1,1997 & & \\
\hline \multirow{2}{*}{$\begin{array}{l}\text { Kişisel } \\
\text { Düzenleme }\end{array}$} & Erkek & 74 & 4,225 & 0,9886 & \multirow{2}{*}{2,531} & \multirow[b]{2}{*}{, 013} \\
\hline & Kadın & 51 & 3,719 & 1,1688 & & \\
\hline \multirow{2}{*}{$\begin{array}{l}\text { Dışsal Düzenleme } \\
\text { Maddi }\end{array}$} & Erkek & 74 & 3,639 & 1,0537 & \multirow{2}{*}{1,211} & \multirow{2}{*}{,204 } \\
\hline & Kadın & 51 & 3,849 & 0,7840 & & \\
\hline \multirow{2}{*}{$\begin{array}{l}\text { Dişsal düzenleme } \\
\text { Sosyal }\end{array}$} & Erkek & 74 & 3,666 & 1,0218 & \multirow{2}{*}{, 072} & \multirow{2}{*}{,943 } \\
\hline & Kadın & 51 & 3,653 & 0,9544 & & \\
\hline \multirow{2}{*}{$\begin{array}{l}\text { İce Yansitılan } \\
\text { Düzenleme }\end{array}$} & Erkek & 74 & 3,851 & 1,0499 & \multirow{2}{*}{1,271} & \multirow{2}{*}{,206 } \\
\hline & Kadın & 51 & 3,594 & 1,1912 & & \\
\hline \multirow{2}{*}{ İçsel Motivasyon } & Erkek & 74 & 3,815 & 0,9284 & \multirow{2}{*}{2,770} & \multirow{2}{*}{,007 } \\
\hline & Kadın & 51 & 3,281 & 1,1418 & & \\
\hline
\end{tabular}


$\mathrm{Bu}$ boyutlardan kişisel düzenleme boyutu ortalamalarına bakıldığında erkeklerin $(4,225)$ ile kadınlardan $(3,719)$ daha fazla, işe kişisel değer atfettikleri görülmektedir. İçsel Motivasyon alt boyutuna bakıldığında yine erkeklerin $(3,815)$ ile kadınlardan $(3,281)$ daha fazla bir ortalamaya sahip oldukları, iş motivasyonlarında işlerinin heyecan verici ve eğlenceli olmasının önemli olduğu ve işlerini kadınlara göre daha ilginç ve heyecan verici buldukları saptanmıştır. Kadın ve erkeklerin ortalamalarına bakıldığında her iki grup içinde maddi unsurların önemli görülmesine rağmen manevi unsurların daha önemli olduğu görülmektedir.

Departmanlara göre çalışanların motivasyonlarının farklılaştığı alanları belirlemek üzere anova testi uygulanmıștır. Anova testinde varyansların homojenliği test edildiğinde motive olmama (Sig. ,001), dışsal düzenleme maddi (Sig.,001) ve içe yansıtılan düzenleme (Sig. ,024) homojen olmadıkları görülmüştür. Bu yüzden bu boyutlar için Tamhane's T2 testi uygulanmıştır. Kişisel Düzenleme (Sig. ,464), dışsal düzenleme sosyal (Sig. ,430) ve içsel motivasyon (Sig. ,388) boyutlarının ise homojen dağıldıkları belirlenerek Tukey testi uygulanmıştır. Homojen dağılan ve dağılmayan boyutlara ilişkin veriler Tablo 4 ve Tablo 5 'de verilmiştir.

Tablo 4: Çalışanların Çalıştıkları Departmana İş Motivasyonu Durumları

(Homojen dağılmayan boyutların Anova analizleri)

\begin{tabular}{|c|c|c|c|c|c|c|c|c|}
\hline & Gruplar & Ort & SS & & KT & KO & $\mathbf{F}$ & p \\
\hline \multirow{4}{*}{$\begin{array}{l}\text { Motive } \\
\text { Olmama }\end{array}$} & $\mathrm{H} / \mathrm{K}$ & 3,047 & 1,3508 & & & & \multirow{4}{*}{7,226} & \multirow{4}{*}{, 000} \\
\hline & Servis & 2,614 & 1,1947 & G.Ara & 27,697 & 9,232 & & \\
\hline & Mutfak & 3,266 & 1,1460 & G.İçi & 154,602 & 1,278 & & \\
\hline & Önbüro & 2,057 & 0,8224 & & & & & \\
\hline \multirow{4}{*}{$\begin{array}{l}\text { Dişsal } \\
\text { Düzenleme } \\
\text { Maddi }\end{array}$} & $\mathrm{H} / \mathrm{K}$ & 3,940 & 0,5812 & & & & \multirow{4}{*}{,984 } & \multirow{4}{*}{, 403} \\
\hline & Servis & 3,583 & 1,0506 & G.Ara & 2,695 & ,898 & & \\
\hline & Mutfak & 3,588 & 1,2276 & G.İçi & 110,430 & ,913 & & \\
\hline & Önbüro & 3,800 & 0,8292 & & & & & \\
\hline \multirow{4}{*}{$\begin{array}{l}\text { İçe } \\
\text { Yansitılan } \\
\text { Düzenleme }\end{array}$} & $\mathrm{H} / \mathrm{K}$ & 3,928 & 1,1271 & & & & \multirow{4}{*}{5,725} & \multirow{4}{*}{,001 } \\
\hline & Servis & 3,135 & 1,2696 & G.Ara & 19,069 & 6,356 & & \\
\hline & Mutfak & 4,200 & 0,8736 & G.İçi & 134,353 & 1,110 & & \\
\hline & Önbüro & 3,771 & 0,9066 & & & & & \\
\hline
\end{tabular}

Anova analizi sonucunda motive olmama alt boyutunda ve içe yansitılan düzenleme alt boyutunda gruplar arasında anlamlı farklılıklar olduğu görülmektedir. Bu farklılıkların hangi gruplar arasında olduğunu görmek için ortalamalara bakıldığında motive olmama alt boyutunda kat hizmetleri ile önbüro arasında ve mutfak ile önbüro arasında anlamlı bir fark olduğu görülmektedir. İçe yansitılan düzenleme boyutunda ise mutfak ile servis arasında anlamlı farklılık bulunduğu ortaya çıkmıştır. Grupların ortalamaları incelendiğinde Motive olmama boyutunda kat hizmetlerinin $(3,047)$ ortalama ile önbüro $(2,057)$ 'ya göre daha çok motive olmadığ1 görülmüştür. Mutfak $(3,266)$ ile öbüro $(2,057)$ ortalamaları incelendiğinde yine mutfak departmanının daha çok motive olmadığı ortaya çıkmaktadır. İçe yansıtılan düzenleme boyutunda, servis $(3,135)$ ve Mutfak $(4.200)$ ortalamaya sahip oldukları ve bu sonuca göre mutfak çalışanlarının servis çalışanlarına göre işlerinde sarf ettikleri çabanın kişisel olarak hissedecekleri utanç ve suçluluk duygusu gibi hislerden kaçınma sonucu ortaya çıkan motivasyonun daha ağır bastığı görülmektedir.

Homojen dağılan boyutlar için yapılan analiz sonuçlarına göre anova analizi Tablo 5'de verilmiştir. Bu tabloya göre gruplar arasında iş motivasyonunun kişisel düzenleme, dışsal düzenleme sosyal ve içsel motivasyon alt boyutlarında herhangi bir anlamlı farklılık ortaya çıkmadığı görülmektedir.

Tablo 5: Çalışanların Çalıştıkları Departmana İş Motivasyonu Durumları

(Homojen Dağılan Boyutların Anova Analizi)

\begin{tabular}{|c|c|c|c|c|c|c|c|c|}
\hline & Gruplar & Ort & SS & & KT & KO & $\mathbf{F}$ & p \\
\hline \multirow{4}{*}{$\begin{array}{l}\text { Kişisel } \\
\text { Düzenleme }\end{array}$} & $\mathrm{H} / \mathrm{K}$ & 3,619 & 1,2025 & & & & \multirow{4}{*}{,779 } & \multirow{4}{*}{, 155} \\
\hline & Servis & 4,041 & 0,9828 & G.Ara & 6,225 & 2,075 & & \\
\hline & Mutfak & 4,211 & 1,1727 & G.İçi & 141,176 & 1,167 & & \\
\hline & Önbüro & 4,152 & 0,9746 & & & & & \\
\hline \multirow{4}{*}{$\begin{array}{l}\text { Dişsal } \\
\text { Düzenleme } \\
\text { Sosyal }\end{array}$} & $\mathrm{H} / \mathrm{K}$ & 3,785 & 1,0932 & & & & \multirow{4}{*}{379} & \multirow{4}{*}{,073 } \\
\hline & Servis & 3,302 & 1,0654 & G.Ara & 6,783 & 2,261 & & \\
\hline & Mutfak & 3,933 & 0,8368 & G.İçi & 114,991 & ,950 & & \\
\hline & Önbüro & 3,657 & 0,8947 & & & & & \\
\hline \multirow{4}{*}{$\begin{array}{l}\text { İçsel } \\
\text { Motivasyon }\end{array}$} & $\mathrm{H} / \mathrm{K}$ & 3,321 & 1,1880 & & & & \multirow{4}{*}{,897 } & \multirow{4}{*}{, 134} \\
\hline & Servis & 3,572 & 0,9809 & G.Ara & 6,144 & 2,048 & & \\
\hline & Mutfak & 3,955 & 1,1703 & G.İçi & 130,589 & 1,079 & & \\
\hline & Önbüro & 3,533 & 0,8212 & & & & & \\
\hline
\end{tabular}


Otel çalışanlarının eğitim durumlarına göre iş motivasyonlarının belirlenmesi amacıyla uygulanan anova analizinde homojen dağılmayan boyutlara ilişkin sonuçlar Tablo 6'da verilmiştir. Homojen dağılmayan boyutlar için Tamhane 2 testi uygulanmıştır.

Tablo 6: Çalışanların Eğitim Durumlarına Göre İş motivasyonu Durumları

\begin{tabular}{|c|c|c|c|c|c|c|c|c|}
\hline & Gruplar & Ort & SS & & KT & KO & $\mathbf{F}$ & p \\
\hline \multirow{5}{*}{$\begin{array}{l}\text { Motive } \\
\text { Olmama }\end{array}$} & İlkokul & 2,435 & 1,3008 & & & & \multirow{5}{*}{6,838} & \multirow{5}{*}{,000 } \\
\hline & Ortaokul & 3,814 & 1,0799 & G.Ara & 33,840 & 8,460 & & \\
\hline & Lise & 2,578 & 1,2343 & G.İçi & 148,459 & 1,237 & & \\
\hline & Önlisans & 2,828 & 1,0805 & & & & & \\
\hline & Lisans & 2,058 & 0,8143 & & & & & \\
\hline \multirow{5}{*}{$\begin{array}{l}\text { İçe } \\
\text { Yansitılan } \\
\text { Düzenleme }\end{array}$} & İlkokul & 3,692 & 1,2580 & & & & \multirow{5}{*}{4,670} & \multirow{5}{*}{,002 } \\
\hline & Ortaokul & 4,481 & 0,5267 & G.Ara & 20,666 & 5,166 & & \\
\hline & Lise & 3,508 & 0,9886 & G.İçi & 132,756 & 1,106 & & \\
\hline & Önlisans & 4,030 & 1,0420 & & & & & \\
\hline & Lisans & 3,492 & 0,9173 & & & & & \\
\hline \multirow{5}{*}{$\begin{array}{l}\text { İçsel } \\
\text { Motivasyon }\end{array}$} & İlkokul & 3,051 & 1,1373 & & & & \multirow{5}{*}{3,526} & \multirow{5}{*}{,009 } \\
\hline & Ortaokul & 4,111 & 0,6049 & G.Ara & 14,381 & 3,595 & & \\
\hline & Lise & 3,403 & 1,2403 & G.İçi & 122,351 & 1,020 & & \\
\hline & Önlisans & 3,909 & 0,9401 & & & & & \\
\hline & Lisans & 3,376 & 0,8366 & & & & & \\
\hline
\end{tabular}

Eğitim durumlarına göre gruplar arasındaki farklılıklara bakıldığında ortaokul mezunu çalışanların diğer okul mezunlarından motive olmama boyutunda anlamlı bir şekilde farklılaştıkları görülmektedir. $\mathrm{Bu}$ çalışmanın uygulandığı otel işletmelerinde çalışan ortaokul mezunlarının diğer mezunlara göre yaptıkları işlerde daha az motive oldukları görülmüştür. Tablo 6'da içe yansıtılan düzenleme boyutu incelendiğinde ortaokul mezunlarının lise ve lisans mezunlarıyla anlamlı şekilde farklılaştığı, önlisans mezunlarının ise lise mezunlarıyla anlamlı şekilde farklılaştı̆̆ görülmektedir. Ortaokul ve önlisans mezunlarının diğer gruplara göre, iş motivasyonlarında daha baskın kişisel duyguların etkisi olduğu söylenebilir. İçsel motivasyon boyutu incelendiğinde ortaokul mezunlarının diğer gruplardan farklılaştığı ve işlerini heyecanlı ve eğlenceli bulmalarının iş motivasyonlarında önemli olduğu görülmektedir.

Homojen dağılmayan boyutlara ilişkin anova analiz sonuçları Tablo 7'de verilmiştir. Bu boyutlar için gruplar arasındaki farlılıklara bakıldığında yalnızca "dıssal düzenleme sosyal” boyutunda anlamlı bir farklılık olduğu görülmektedir.

Tablo 7: Çalışanların Eğitim Durumlarına Göre İş motivasyonu Durumları

(Homojen Dağılan Boyutların Anova Analizleri)

\begin{tabular}{|c|c|c|c|c|c|c|c|c|}
\hline & Gruplar & Ort. & SS & & KT & KO & $\mathbf{F}$ & p \\
\hline \multirow{5}{*}{$\begin{array}{l}\text { Kişisel } \\
\text { Düzenleme }\end{array}$} & İlkokul & 4,051 & 0,7557 & & & & \multirow{5}{*}{, 856} & \multirow{5}{*}{,492 } \\
\hline & Ortaokul & 4,425 & 0,7567 & G.Ara & 4,091 & 1,023 & & \\
\hline & Lise & 3,921 & 1,0778 & G.İçi & 143,310 & 1,194 & & \\
\hline & Önlisans & 4,020 & 1,1147 & & & & & \\
\hline & Lisans & 3,840 & 1,4137 & & & & & \\
\hline \multirow{5}{*}{$\begin{array}{l}\text { Dişsal } \\
\text { Düzenleme } \\
\text { Maddi }\end{array}$} & İlkokul & 3,564 & 0,6719 & & & & \multirow{5}{*}{, 370} & \multirow{5}{*}{,829 } \\
\hline & Ortaokul & 3,944 & 1,1673 & G.Ara & 1,379 &, 345 & & \\
\hline & Lise & 3,745 & 1,0524 & G.İçi & 111,746 & ,931 & & \\
\hline & Önlisans & 3,656 & 0,8395 & & & & & \\
\hline & Lisans & 3,711 & 0,9444 & & & & & \\
\hline \multirow{5}{*}{$\begin{array}{l}\text { Dişsal } \\
\text { Düzenleme } \\
\text { Sosyal }\end{array}$} & İlkokul & 3,538 & 1,0141 & & & & \multirow{5}{*}{4,237} & \multirow{5}{*}{,003 } \\
\hline & Ortaokul & 4,481 & 0,5389 & G.Ara & 15,071 & 3,768 & & \\
\hline & Lise & 3,508 & 0,9886 & G.İçi & 106,703 &, 889 & & \\
\hline & Önlisans & 3,636 & 1,0420 & & & & & \\
\hline & Lisans & 3,376 & 0,9173 & & & & & \\
\hline
\end{tabular}

Dışsal düzenleme sosyal, boyutunda bütün grupların ortalamalarının genel olarak yüksek olduğu fakat ortaokul mezunlarının diğerlerine göre daha yüksek olduğu görülmektedir. Bu sonuç tüm gruplar için sosyal ve manevi kazanç ya da kayıpların iş motivasyonlarında etkili olmasına rağmen ortaokul mezunlarının bu tür beğeni ya da yergileri daha çok önemsedikleri görülmektedir. 
Tablo 8: Çalışanların Eğitim Durumlarına Göre Çalıştıkları Departman Dağılımları

\begin{tabular}{lcccccc}
\hline & İlkokul & Ortaokul & Lise & $\begin{array}{c}\text { Ön } \\
\text { Lisans }\end{array}$ & Lisans & Toplam \\
\hline H/K & 9 & 6 & 6 & 5 & 2 & 28 \\
\hline Servis & 3 & 3 & 16 & 8 & 2 & 32 \\
\hline Mutfak & - & 6 & 12 & 8 & 4 & 30 \\
\hline Ön Büro & 1 & 3 & 4 & 12 & 15 & 35 \\
\hline Toplam & 13 & 18 & 38 & 33 & 23 & 125
\end{tabular}

Dağılımlara bakıldığında departman olarak motive olamama boyutunda yüksek skora sahip kat hizmetleri ve mutfak departmanı çalışanlarının, eğitim düzeyleri dağılımlarında da yüksek skora sahip ortaokul mezunlarından oluştukları görülmektedir. Bu sonuç ortaokul mezunlarının neden diğer mezunlardan motive olamama konusunda önemli ölçüde farklılaştığını açıklamakta yardımcı olmaktadır. Aslında mezun olunan okulun iş motivasyonu boyutlarından motive olamama boyutuna etkisinden ziyade çalışılan departmandan kaynaklı bir durumun söz konusu olduğu, ortaokul mezunlarının bu gruplarda ağırlıklı olmasıyla açıklanabilir.

Çeşitli demografik değişkenlere göre gerçekleştirilen analizler genel olarak incelendiğinde otel çalışanlarının erkek ve kadın fark etmeksizin maddi dışsal motivasyon unsurlarından etkilendiği fakat içsel motivasyon unsurlarının motive olmalarında daha etkili olduğu görülmektedir. Çalıştıkları departmanlara göre bakıldığında mutfak çalışanlarının diğerlerine göre içsel motivasyonu oluşturan boyutlarda daha yüksek ortalamalara sahip olduğu, kat hizmetleri çalışanlarının motivasyonlarında ise dışsal unsurların daha etkili olduğu görülmektedir. Eğitim durularına göre yapılan analizlerde ortaokul mezunu çalışanların içsel ve dışsal motivasyon faktörlerinden yüksek derecede etkilendiği, tüm gruplarda işe atfedilen değerin oldukça yüksek olduğu ve lisans mezunlarının daha fazla işe motive olabildikleri ortaya çıkmıştır.

\section{SONUÇ VE ÖNERILER}

Turizm, hizmetler sektörü içinde yer alan ve hizmet üretiminde emeğin yani insan faktörünün en önemli unsur olduğu, işletme verimliliğinin büyük ölçüde çalışan performansına dayalı olduğu alanların başında gelmektedir. Turizm işletmeleri içinde oldukça önemli bir yere sahip otel işletmeleri içinde bu durum değişmemektedir. Çalışanların verimliliğinin otel işletmeleri için oldukça önemli olması çalışanların verimlerini etkileyen iş motivasyonlarının belirlenmesini ve farklılaştığı boyutların bilinmesini ve farklılaşma nedenlerinin bulunarak gruplar arasında dengeli ve etkili performans düzeylerinin yakalanabilmesine olanak sağlayacaktır. Çünkü otel işletmelerinde insanların yaptıkları işler birbirleriyle ilişkili ve birbirlerinden etkilenen bir yapıdadır. Dolayısıyla bir grubun iş performansı diğer gruplarla dengeli olmazsa genel iş performansları düşüş gösterecektir.

Çalışma sonucunda elde edilen verilerin değerlendirilmesi ile erkeklerin kadınlara oranla işlerine daha fazla kişisel değer atfettikleri, işlerini bir anlamda kişisel dünyaları ile birlikte algılama oranlarının yüksek olduğu ve işlerini daha ilginç buldukları ortaya çıkmıştır. Bu durum erkek çalışanların işlerini yapılmaya değer bir iş olarak gördüklerini ve işlerinin kişiliklerine daha uygun olduğu (Başaran, 1984) anlamlarına gelebilir. Ancak burada incelenmesi gereken bir diğer sorun ortaya çıkmaktadır. $\mathrm{O}$ da işe başvuru aşamasında erkek adayların daha fazla seçenek içerisinden kendilerine en uygun olanlara başvururken, kadın adayların çok fazla seçeneğe sahip olup olmadı̆̆ıdır. Kadınların otel işletmelerinde genellikle belirli departmanlar dışında çok fazla talep edilmediği (Yetkin, 2017) onların içsel motivasyonlarında azaltıcı bir rol oynadığı düşünülebilir.

Çalıştıkları departmanlar açısından çalışanların motivasyon durumları çalışmanın önemli sonuçlarından birini oluşturmaktadır. Yukarıda bahsedildiği üzere otel işletmeleri bir sistem olarak ele alındığında bu sistemi oluşturan tüm parçaların dengeli çalışması hizmet kalitesinin sağlanması açısından önemlidir. Bu yüzden departmanlar arasında çok boyutlu iş motivasyonu boyutları farklılıkları karşılaştııılmıştır. Kat hizmetleri ve mutfak departmanları çalışanlarının servis ve ön büro departmanları çalışanlarına göre daha az motive oldukları ortaya çıkmıştır. İçe yansıtılan düzenleme boyutunda, mutfak çalışanlarının servis çalışanlarına göre işlerinde sarf ettikleri çabanın kişisel olarak hissedecekleri utanç ve suçluluk duygusu gibi hislerden kaçınma sonucu ortaya çıkan motivasyonun daha ağır bastığı görülmüştür. Çok boyutlu iş motivasyonu boyutlarının dağılımına bakıldığında genel olarak tüm departmanlarda çalışanların motivasyon düzeylerinin orta seviyenin üstünde olduğu görülmektedir. Motive olmama boyutunda ortalamanın üstünde olan kat hizmetleri ve mutfak departmanlarına ilişkin motive olamamalarına sebep kaynakların tespit edilerek bunların giderilmesi işletmelerde departmanlar arası farkın azaltılarak verimliliğin artırılmasına katkı sağlayacaktır.

Eğitim durumlarına göre gruplar arasındaki farkların incelenmesi sonucu ortaokul ve ön lisans mezunlarının orta seviyenin üzerinde motive olamadıkları ve diğer gruplardan farklılaştıkları görülmüştür. Fakat özellikle ortaokul mezunlarının ortalamasının yüksek çıkması nedeniyle bu grubun departmanlar göre dağılımı 
incelenmiş ve motive olamama durumunun departmanla daha fazla ilişkili olabileceği sonucuna ulaşılmıştır. Ancak bu sonucun daha ayrıntılı olarak ele alınması gerekmektedir.

Denizli ilinde faaliyet gösteren şehir oteli çalışanlarının iş motivasyonlarının belirlenmesi ve çeşitli demografik gruplar arasındaki farkların belirlenmesi amacıyla, çok boyutlu iş motivasyonu ölçeği kullanılarak bu çalışma gerçekleştirilmiştir. Çalışmada gruplar arasındaki farkların nedenleri ele alınmamıştır. İşletmelerde çalışanların motivasyonlarının yükseltilerek verimlerinin artırılması için farkların nedenlerinin de belirlenmesi önemli olduğundan motivasyon konusunda çalışmakta olan diğer araştırmacılar için bu konuda çalışılması önerilmektedir.

Bu çalışmadan elde edilen bulgular neticesinde Denizli'deki otel işletmelerinde çalışanları üzerinde maddi motivasyon unsurlarının önemli olmasına rağmen, manevi unsurların biraz daha ağır bastığı görülmektedir. Diğer alanlarda yapılan çeşitli çalışmalarda da Türkiye'deki işletmelerde hem maddi hemde manevi unsurların motivasyon üzerinde olumlu etkiye sahip olduğu belirlenmiştir ( Öztürk ve Dündar, 2003; Ölçer, 2005; Dündar vd., 2007; Cabar ve Serinkan, 2009; Ünsar vd., 2010; Naldöken vd., 2011; Y1ldırım, 2011; Gökkaya ve Türker, 2018). HRthinks Eğitim ve Danışmanlık tarafından 2018 yılında yapılan bir araştırmaya göre Türkiye'de beyaz yakalıların sadece \%8,9'u parayı birinci dereceden motivasyon unsuru olarak görürken, \%57,9'u parayı önemli bir motivasyon unsuru olarak görmemektedir (Marketing Türkiye, 2018). Bu araştırma, kapsadığ1 evrenin özelliği itibari ile maddi bir unsur olan paraya çok fazla önem atfetmemiş olmasına rağmen, genel olarak Türk çalışanlar açısından manevi unsurların önemli olduğunu gösterdiği için önemlidir. Bütün bu bilgiler değerlendirildiğinde ve çalışma sonuçları incelendiğinde otel işletmelerine çalışanların kendilerini huzurlu hissedecekleri ve manevi olarak kendilerini tatmin edecek bir ortamın daha yüksek bir motivasyon sağlayacağını söylemek mümkündür. Ancak bu ortamın çalışanların temel maddi ihtiyaçlarının karşılandıktan sonra etkili olabileceği unutulmamalıdır.

$\mathrm{Bu}$ çalışma genel olarak otel çalışanlarının iş motivasyon düzeylerinin tespit edilmesi ve gruplar arasındaki farkların ortaya konması amacıyla gerçekleştirilmiştir. Çalışmanın, araştırma sonucunda ortaya çıkan sonuçlar ve otel işletmelerine yönelik çeşitli önerileri yanında, bu konuda bir çerçeve oluşturması ve sonraki çalışmalara yol göstermesi umulmaktadır. 


\section{KAYNAKÇA}

Akova, O., Tanrıverdi, H. ve Kahraman, O. C. (2015). Otel İşletmelerinde İşgören Devir Hızına Etki Eden Risk Faktörlerinin Belirlenmesine Yönelik Bir Araştırma. Süleyman Demirel Üniversitesi Vizyoner Dergisi, 6 (12), 87 107.

Akova, O., Kuşluvan, H. ve Çifçi, İ. (2015). Turizm İşletmelerinde Örgütsel Davranış. (Ed. Akova, O., Kızılırmak, İ. ve Tanrıverdi, H.), Turizm İşletmeciliği Temel Kavramlar ve Uygulamalar, Ankara: Detay Yayıncılık.

Başaran, İ. E. (1984). Örgütsel Davranışın Yönetimi. Ankara: A.Ü.E.B.F. Yayınları No: 135

Brief, A. P. \& Aldag, R .J. (1976). The Instrinsic - Extrinsic Dichotomy: Toward Conceptual Clarity, Academy of Management Review, 2(3), 496-500.

Burger, J. M. (2006). Kişilik. İstanbul: Kaknüs Yayınları.

Büyüköztürk, Ş. (2016). Sosyal Bilimler İçin Veri Analizi El Kitabı İstatistik Araştırma Deseni Spss Uygulamaları ve Yorum, Ankara: Pegem Akademi.

Cabar, H., Serinkan, C. (2009). Hemşirelerin çalışma motivasyonunu etkileyen faktörler: Denizli devlet hastanesinde yapılan bir araştırma. Üçüncü Sektör Kooperatifcilik, 44(4), 50-66.

Cherrington, D.J. (1994). Organizational Behavior: The Management of Individual \& Organizational Performance. Boston: Allyn \&Bacon.

Çetin, İ. (2013). Motivation And It's Impact on Labour Productivity at Hotel Business "A Conceptual Study". International Journal of New Trends in Arts, Sports \& Scince Education 2 (1). 70-79

Çivilidağ, A. ve Şekercioğlu, G. (2017). Çok Boyutlu İş Motivasyonu Ölçeğinin Türk Kültürüne Uyarlanması. Mediterranean Journal of Humanities, VII(1), 143-156.

Dündar, S. Özutku, H. ve Taşpınar, F. (2007). İçsel ve Dıı̧sal Motivasyon Araçlarının İşgörenlerin Motivasyonu Üzerindeki Etkisi: Ampirik Bir İnceleme. Ticaret ve Turizm Eğitim Fakültesi Dergisi, 2007(2), 105-119.

Efil, İ. (2006). Yönetim ve Organizasyon. İstanbul: Alfa Aktüel Yayınları.

Eren, E. (2010). Örgütsel Davranış ve Yönetim Psikolojisi. İstanbul: Beta Basım Yayın.

Gagné M., Forest J., Gilbert M. H., Aubé C., Morin E. and Malorni A. (2010). The Motivation at Work Scale: Validation Evidence in Two Languages. Educational and Psychological Measurement, 70(4), 628-646.

Gagné M., Forest J., Vansteenkiste M., Braud L.C., Broeck A.V., Aspeli A. K., Bellerose J., Benabou C., Chemolli E., Güntert S.T., Halvari H., Indiyastuti D.L., Johnson P.A., Molstad M.H., Naudin M., Ndao A., Olafsen A.H., Roussel P., Wang Z. and Westbye C. (2015). The Multidimensional Work Motivation Scale: Validation Evidence in Seven Languages and Nine Countries. European Journal of Work and Organizational Psychology, 24(2), 178196.

Garih, Ü. (2005) İş Hayatında Motivasyon, İstanbul: Hayat Yayıncılık.

Gökkaya, S. ve Türker, N. (2018). İş Motivasyonu İle İş Tatmini Üzerine Otel İşletmelerinde Karşılaştırmalı Bir Araştırma. İktisadi İdari ve Siyasal Araştırmalar Dergisi, 3(5), 12-28.

Güler, E. G., Demiralay, T. ve Selvi, F. (2017). Konaklama İşletmelerinde Motivasyon Araçlarının İşdoyumu Üzerine Etkisi: Edirne Otellerinde Bir Araştırma. Uluslararası Sosyal ve Ekonomik Bilimler Dergisi, 7(2), 31-38.

Herzberg F. (1974). Motivation-Hygiene Profiles: Pinpointing What Ails the Organization. Organizational Dynamics, $3(2), 18-29$.

Kanfer, R. \& Chen, G. (2016). Motivation in Organizational Behavior: History, Advances and Prospects. Organizational Behavior and Human Decision Processes, 136, 6-19.

Karasar, N., (2005). Bilimsel Araştırma Yöntemi. Ankara: Nobel Yayın Dağıtım.

Kaya, İ. (2007) Otel İşletmeleri İşgörenlerinin İş̧ Tatminini Etkileyen Faktörler: Geliştirilen Bir İş Tatmin Ölçeği. Anadolu Üniversitesi Sosyal Bilimler Dergisi, 7(2), 355-372.

Koçel, T. (1989). İşletme Yöneticiliği - Yönetici Geliştirme, Organizasyon ve Davranış. İstanbul: Yön Ajans.

Latham, G.P. (2007). Work Motivation History, Theory, Research and Practice. California: Sage Puplications.

Luthans, F. (2010). Organizatioanal Behavior, 12th Ed. New York: McGraw-Hill.

Marketing Türkiye (2018). Türk iş dünyasının motivasyon haritası yayınlandı. https://www.marketingturkiye.com.tr/haberler/turk-is-dunyasinin-motivasyon-haritasi-yayinlandi/ Erişim Tarihi: 24.08.2019.

McGregor, D.M. (1957). The human side of the enterprise. Management Review, 46, 22-28

McGregor, D.M. (1960). The Human Side of the Enterprise. New York: McGraw-Hill.

Metle, M. (2001). Education, Job Satisfaction and Gender in Kuwait. The International Journal of Human Resource Management, 12(2), 311- 332.

Mullins, L.J. (2010). Management and Organisational Behavior (9th Ed.). Essex: Pearson, FT Prentice Hall

Naldöken Ü., Ekinci H., Biçer E.B. (2011). Bir Devlet Hastanesinde Ek Ödeme Yapılmasının Işgören Motivasyonu Üzerindeki Etkileri. Cumhuriyet Üniversitesi İktisadi ve İdari Bilimler Fakültesi Dergisi, 12(2), 283-295.

Ölçer, F. (2005). Departmanlı Mağazalarda Motivasyon Üzerine Bir Araştırma. Erciyes Üniversitesi İktisadi ve İdari Bilimler Fakültesi Dergisi, 25, 3-75.

Özer, P. S. ve Topaloğlu, T. (2008). Motivasyonda Kapsam Kuramları. Liderlik ve Motivasyon Geleneksel ve Güncel Yaklaşımlar (Ed. Serinkan, C.) Ankara: Nobel Yayın Dağıtım, ss.83-104. 
Özkalp, E. ve Kırel, Ç. (2016). Örgütsel Davranış (7. Baskı), Bursa: Ekin Basın Yayın Dağıtım.

Öztürk, Z., Dündar, H. (2003). Örgütsel Motivasyon Ve Kamu Çalışanlarını Motive Eden Faktörler. Ç.Ü. İktisadi ve İdari Bilimler Dergisi, 4(2), 57-67.

Pinder, C.C. (1998). Work Motivation in Organizational Behavior. Saddle River, New Jersey: Prentice Hall

Porter, L., Bigley, G.A. \& Steers, R.M. (2003). Motivation and Work Behavior. New York: McGraw-Hill.

Robbins, S.P. (1996). Organizational Behavior: Concepts, Controversies, Applications. (7th Ed.) Englewood Cliffs, New Jersey: Prentice Hall

Robbins, S.P. (2003). Essentials of Organizational Behavior. New Jersey: Prentice Hall.

Seker, S.E. (2015). Motivasyon Teorisi. YBS Ansiklopedi, 2(1), 22-26.

Smit, P.J., Cronje G.E., Brevis T. \& Vrba M .J. (2011). Management Principles: A Contemporary Edition for Africa (5th Ed.). Cape Town: Juta Publishers

Steers, R.M., Mowday, R.T. and Shapiro, D.L. (2004). The Future of Work Motivation Theory. Academy of Management Review, 29(3), 379-387.

Stroh, L. K., Northcraft, G. B. \& Neale M. A. (2008). Organizational Behavior: A Management Challenge. Taylor \& Francis e-library

Şimşek, Ş. (1995). Yönetim ve Organizasyon. Konya: Damla Matbaacılık.

Tütüncü, Ö. ve Demir, M. (2002). Konaklama İşletmelerinde İnsan Kaynakları Yönetimi ve İşgücü Hareketlerinin Analizi. Ankara: Turhan Kitabevi.

Ural, A. ve Kılıç, İ. (2006). Bilimsel Araştırma Süreci ve SPSS ile Veri Analizi. Ankara: Detay Yayıncılık.

Ünsar, A. S., İnan, A. ve Yürük, P. (2010). Çalışma Hayatında Motivasyon ve Kişiyi Motive Eden Faktörler: Bir Alan Araştırması. Trakya Üniversitesi Sosyal Bilimler Dergisi, 12(1), 248-262.

Yetkin, D. (2017). Turizm Sektöründe Kadın, http://hotelgazetesi.com/yazi-detay/122/turizm-sektorunde-kadin. Erişim Tarihi: 17.10 .2018

Yıldırım, N. (2011). Okul Müdürlerinin Motivasyonları Üzerine Nitel Bir İnceleme. Abant İzzet Baysal Üniversitesi Eğitim Fakültesi Dergisi, 11(1), 71-85.

Yüksel, Ö. (2000). İnsan Kaynakları Yönetimi. Ankara: Gazi Kitapevi. 